\title{
Researching climate change and community in neoliberal contexts: an emerging critical approach
}

\author{
Gerald Taylor Aiken, ${ }^{1 *}$ Lucie Middlemiss, ${ }^{2}$ Susannah Sallu ${ }^{3,4}$ and \\ Richard Hauxwell-Baldwin ${ }^{5}$
}

Edited by Mike Hulme, Domain Editor and Editor-in-Chief

In a 2011 contribution to this journal, Walker examined the ways that community is routinely employed in carbon governance, suggesting the need for more critical approaches. Here, we characterize an emerging, critical approach to researching climate change and community in neoliberal contexts, focusing attention principally on the global north, where this body of research has emerged. This work recognizes communities as sites of contestation, difference, tension, and distinction, in which action on climate change can be designed to meet a range of political and public ends. It aims to uncover the political and social context for community action on climate change, to be alert to the power relations inside and outside of communities, and to the context of neoliberalism, including individualism, the will to quantify, and competition. Furthermore, research in this space is committed to understanding both the lived experience of the messy empirical worlds we encounter, and the potential agency coalescing in community responses to climate change. Much of the work to date, discussed here, has focused on communities working on climate change mitigation in the global north, in which the idea of community as a space for governance is gaining traction. We also comment on the positioning of these arguments in the context of long-standing debates in the fields of 'community-based' development, natural resource management, and adaptation in the global South. This discussion establishes a foundation from which to progress learning across fields and geopolitical boundaries, furthering critical thinking on 'community.' ๑ 2017 Wiley Periodicals, Inc.

How to cite this article:

WIREs Clim Change 2017, e463. doi: 10.1002/wcc.463

*Correspondence to: gerald.aiken@uni.lu

${ }^{1}$ Institut de Géographie et Aménagement du Territoire, Universite du Luxembourg. Maison des Sciences Humaines, 11, Porte des Sciences, L-4366, Esch-sur-Alzette, Groussherzogtum, Lëtzebuerg

${ }^{2}$ Sustainability Research Institute, School of Earth and Environment, University of Leeds, Leeds, UK

${ }^{3}$ ESRC Centre for Climate Change Economics and Policy, University of Leeds, Leeds, UK

${ }^{4}$ Centre for Global Development, University of Leeds, Leeds, UK

${ }^{5}$ School of Environmental Sciences, University of East Anglia, Norwich, UK

Conflict of interest: The authors have declared no conflicts of interest for this article.

\section{INTRODUCTION}

Tn 2011, Walker reviewed the extant work on the role of community in carbon governance. In his analysis, he suggested the need for a more critical response. He emphasized that:

... a critical perspective needs to be maintained which recognizes that communities are not always inclusive, harmonious and collaborative, or indeed may not exist in any cohesive form ready to take responsibility for climate change action. ${ }^{1}$ 
Walker's call was a reaction to a rather naive tendency, among both academics and policymakers, to attribute extensive power for change to communities, assuming that community is an unproblematic entity through which people can come together to deal with environmental problems. He characterized this view of community as: 'positive, productive and contributing to the successful implementation and social embedding of various forms of carbon reduction activity' (Ref 1, p. 777).

Here, we identify a trend in research on community and climate change that has emerged in the global north, which amounts to a response to Walker's call. This critical approach takes a distinct starting point from the other literatures that engage with climate change and community. It starts from the premise that communities are internally complex, and that relations between communities and other institutions are potentially problematic. It also anticipates that community has different meanings for different institutions and for the various members of the 'community' concerned. This new body of work is acutely alert to the politics and power relations present inside and outside communities. This work also recognizes communities as sites of contestation, difference, tension, and distinction. Finally, this work tries to chart a course between an uncritical celebration of community and the dismissal of community out of hand. ${ }^{2}$

The critical approach we chart here has emerged in reaction to mainstream, uncritical thinking about community prevalent in policy and practice. It may also be a sign of a maturing academic response to the phenomenon of community action on climate change, with the initial rush of enthusiasm for these projects increasingly tempered by messy empirical realities. As such it is not entirely distinct from what goes before. For instance, work in the field of political ecology, largely focused on the global south, has a long history of advocating more critical engagement with communities in relation to development (see Box 1), while the body of work on Grassroots Innovations has engaged peripherally with the politics of community and critical approaches. ${ }^{3,4}$ In effect, critical approaches have grown out of the existing research on community and environment. Yet, we also argue that this critical approach is becoming distinct from these other bodies of research, at least in that outputs are increasingly emerging that are strongly rooted in a particular epistemology and ontology.

This paper outlines the key facets of this new critical approach. First, we document how a critical approach attempts to understand the multiple meanings of community in a particular context, and the ways in which those meanings structure action. Second, we show how this body of work takes an interest in neoliberal contexts for community action on climate change, in particular focusing on the tensions between community and individualism, and the capture of community through numbers. Third, we look at how issues of representation by community play out in this body of work. In Box 1, we also consider the connections between the global south and north, adaptation and mitigation actions in the context of critical approaches to community. Finally, we think about the direction this work is taking, and make some comments on the potential for future work.

\section{THE MULTIPLE MEANINGS OF COMMUNITY AND THEIR FUNCTIONS}

There is a recognized tendency, particularly among policymakers, to conceive of community as an instrument of government, as a means of effecting government policy, or of implementing the values and goals of another institution, at arm's length. Communities or community-based initiatives are seen as a means of communicating messages about government concerns, and persuading people to act differently, through 'trusted intermediaries.' In the UK, the Department for Environment, Food and Rural Affairs' (DEFRA's) Sustainable Development Strategy of 2005 , for example, states that:

Community groups can help tackle climate change, develop community energy and transport projects, help minimize waste, improve the quality of the local environment, and promote fair trade and sustainable consumption and production. ${ }^{25}$

DEFRA sees the function of community here as complimentary to the work of government. Critical research challenges this idea by observing the distance between government understandings of an appropriate societal goal, and the aims and desires of a specific community movement, or the lived reality of any given community for its members. An instrumentalized community is problematic in multiple ways: it depoliticizes the goals that a community is being asked to meet, it risks government co-opting communities to its own ends, it treats the community (and indeed communities) as a unified and monolithic group and it relies on often unpaid or poorly paid community members for government work. ${ }^{26-29}$ 
BOX 1

\section{CRITICAL COMMUNITY AND}

\section{PARTICIPATION IN THE GLOBAL SOUTH}

Critical debates about 'community' in the global south have a longer history, not necessarily bound up in neoliberalism. Increasingly, postcolonial structural adjustment and international donor support have resulted in many developing nations in the global south being heavily influenced by neoliberal policies. Critical debates about community in the global south have evolved in the literature alongside a set of dominant, externally funded, designed, and managed programmatic approaches to development and natural resource governance: Community Development (CD, 1950s and 1960s), Participatory Development (1980s), and Community Based Natural Resource Management (1980s and 1990s). These approaches were rolled out in postcolonial contexts perceived as having weak state-centered policies. ${ }^{5,6}$ Holdcroft argued that 'many leaders of developing nations and external donors viewed $C D$ as the means to mobilize rural people as a resource for and the objective of economics, social and political development' and saw it as an 'appropriate democratic response to the threat of international communism during the Cold War era. ${ }^{7} \mathrm{CD}$ was therefore urged upon British colonial officers and applied in African territories. ${ }^{7}$

Despite clear academic interest in communities, it was not until 'participatory' methods became popular in the global south, ${ }^{8}$ that the focus on 'community' gained prominence and 'community participation' in development and later natural resource management and conservation proliferated. ${ }^{9}$ Widespread preoccupation with a 'mythic community' that is, a community that is small, composed of homogeneous groups using locally evolved norms to live with nature harmoniously and therefore manage resources sustainably and equitably, ${ }^{10}$ failed to include and empower poor and marginalized people in participatory processes. Evidence of elite capture of program benefits, combined with other critiques emerging from the failures of community-based activities resulted in a prolific critical literature. ${ }^{11-16}$ This literature was heavily influenced by political ecology approaches ${ }^{17-20}$ that argued for greater consideration of politics in the environmentdevelopment field at this time. These critical debates provide a foundation for newer approaches, for example, community-based adaptation (CBA), ${ }^{21-23}$ an approach that aims to empower communities to plan for and cope with the impacts of climate change. However, calls for further critical study of CBAs to examine the tensions and challenges that it brings illustrate the challenge of a more critical approach filtering into policy and practice. ${ }^{22}$ While much communities and climate change focus in the global north has been given to mitigation, in the global south, where significant negative impacts on development are expected, attention has focused on adaptation through CBA. With the proliferation of payment for ecosystem services programs in the global south and moves from piloting to implementing REDD+ (climate change mitigation), communities will remain central. ${ }^{24}$ There is currently untapped potential for learning across adaptation and mitigation, global south to north and vice versa, rural to urban and back again.

Community here is what Eadson calls a 'policy object. $^{30}$

Community has historically been linked to a series of semantic meanings. From local community, ${ }^{31}$ community as symbolic function, ${ }^{32}$ imagined community, ${ }^{33}$ or a sense of loss that individuals collectively pursue, ${ }^{34}$ to choose only a few. The emerging critical approach questions the semantic meanings that are linked to community action on climate change. ${ }^{35}$ Critical perspectives challenge the synonyms that are implied wherever community is invoked, but we also go further. For example, when government uses community there is scope for questioning the geographic and scalar assumptions of what makes community, and for unpicking normative assumptions about both what makes a good community, and what makes community good. Critical conceptions of community move beyond reified visions of a harmonious, local, smallscale, utopian social form, as well as dystopian accounts of present day communities as individualized, antisocial and fragmented, or settled, bounded and evaporating. ${ }^{36,37}$

At this point, it is important to directly address just what 'being critical' means, or may come to mean. In this body of work, we observe an understanding of 'being critical' which evokes Horkheimer's famous essay Traditional Theory and Critical Theory. ${ }^{38}$ Horkheimer excoriates what he called 'the savant'-the researcher who fails to realize the underlying structural lineages of their theorizing and 
empirical object of study, or their own involvement or complicity with what they purport to be separate, distant processes. For Horkheimer, the savant is a 'traditional theorist.' Conversely, the 'critical theorist' avoids false universals and is alert to ideological presuppositions and unquestioned shibboleths. In applying this thinking, we take the premise that researching alternatives is not in itself critical. Framing community as an object of study, or even identifying community in the first instance, can reify community, setting it apart, and risk precluding many of community's nuances and idiosyncrasies, or alternative viewpoints. In this new body of work, questioning what community actually does is more critical than questioning what community is. This applies as much to government attempts to instrumentalize community, as it does to civil society or private sector attempts to enlist community affectively.

A critical approach, we argue, begins with awareness of community's polysemy-the various semantic links the concept has in specific contexts. Walker, ${ }^{1}$ for example, points to six common meanings of community, when invoked in environmental contexts. Critical scholars of community are also aware of how it can be used as a meaning-less term, that community performs a phatic function. ${ }^{35}$ The concept can be used for its gestural effects, as, among others, energy companies employ community to generate acceptance from local residents, ${ }^{39}$ or as a 'symbolic resource' to galvanize participants. ${ }^{40}$ The very word community has performative aspects. Transition Towns groups for example aim to 'unleash the power of community' to meet environmental and social aims. ${ }^{41,42}$ Consider the affective technology of community here: any other related synonym would not carry the same force. This is more akin to what Bauman said of community: 'Some words have meaning, others have a feel. ${ }^{34}$

Critical scholars of climate change and community, regularly engage with the multiple meanings of community, and the question 'what does community do. ${ }^{43-51}$ Or, as in Phillips and Dickie's account of community stasis and inaction, what community doesn't do. ${ }^{52}$ Wright $^{36}$ for instance, who is critical of community's persistently positive associations, also points to the variegated experiences of and pursuit of community within the everyday lives of suburban dwellers, which often include a positive vision. Van Veelen and Haggett ${ }^{53}$ show how multiple forms of place attachment form the basis of disagreements in the context of rural renewable energy projects. While locality is one important aspect of community land movements, the community invoked is fundamentally multilayered and multiscalar. ${ }^{54}$ Braunholtz-Speight also outlines the power relations across multiple scales within community land initiatives. ${ }^{55}$ Markantoni and Woolvin draw attention to the variety of communities that are implicated in the transition to low-carbon futures, which go beyond intentional and active community movements. They argue for a 'spatially sensitive approach ${ }^{56}$ in understanding community transitions, drawing particular attention to rural and urban differences in unintentional communities. Büchs et al. notice how low-carbon lifestyle projects in community tend to frame their activities conservatively in order to avoid excluding broader audiences. ${ }^{57}$ In each of these studies, and many more besides, community is neither dismissed out of hand, nor blindly assumed to be known, but met on its own terms.

As a counterpoint to the form of community we are discussing here-social arrangements emerging and deployed in response to environmental challenges-community also has the capacity to 'jump scales.' ${ }^{37,58}$ Here, it should be noted that community sometimes means, or relates to, humanity as a whole. While the community discussed here is often focused on a specifically placed intervention (in a neighborhood, city, business, identity group, etc.), there is regularly, at least at a discursive level, a link to global climate change, global emissions, or global environmental impacts. This scalar splintering and vicariousness (action at one scale on behalf of another) is a central part of the community we discuss here.

When community responds to environmental challenges, much of the latent-and uncriticizedappeal of the term is its capacity to jump scales. The assumption is of a (local) community responding to (global) environmental challenges. ${ }^{37}$ Likewise, work on community low-carbon transitions often assumes a transition toward a localist, and positive, future. Critical approaches do not just repeat Williams's quote that community is 'never used unfavourably, but investigate why this multiple placeholder retains such positive affectations. It is the digging deeper, in this case digging deeper into the scalar implications of community and environment that reveals critical aspects.

Policies on community and climate change often adopt such scalar jumping. ${ }^{60}$ Critical approaches, in mobilizing this understanding both of how meaning plays out across the different scales, and why community is held as a positive force, can help understand policy failure in this area. As Creamer ${ }^{61,62}$ has pointed out, policies promoting community to control climate change can often be counterproductive to 
their aims of utilizing community for environmental aims. The formation of community policy can counter-intuitively, and counterproductively, transform and damage the very community experience or activity it purports to promote.

\section{CRITIQUING COMMUNITY IN WESTERN NEOLIBERAL CONTEXTS}

A critical approach sees the ways these processes come into being and function -how community is used in pursuit of environmental aims and objectives in the global north —as understandable only against the backdrop of an increasing neoliberalism in states (and hence policy) but also concurrently in civil society forms and ways of acting.

Understanding community in this way, to some extent fits a standard analysis of neoliberalism's twopronged modes of operation: rollback and rollout. Rollback neoliberalism involves withdrawing state provision and formal support to achieve national aims and ambitions. Here, community groups and movements are expected to do the work of government in meeting nationally defined carbon reduction targets, as implied in the DEFRA quote above. Rosol $^{63}$ outlines the ways in which community volunteering forms a bridge between rollback neoliberalism-doing state legwork-and rollout neoliberalism-doing so under neoliberal principles. Rollout neoliberalism pushes market techniques, individualism, and abstraction onto more-than-state actors, asking community groups and movements to compete for resources. In neoliberal environmental policy, there is a fine line between attempting to green behavior while also holding the freedom of choice of the individual sacrosanct, as can be seen in applying recent discussions of liberal paternalism to these contexts. ${ }^{64-66}$ This understanding of community is symptomatic of a broader link between libertarian or neoliberal beliefs in a small state, with more anarchic, small-scale motivations and worldviews of grassroots activists. ${ }^{5}$

Critical understandings of community responses to environmental challenges have evolved in a complex, sometimes contradictory, world however; often among scholars who see the value of these initiatives as somewhat countercultural, not purely as a subservient form of neoliberalism. Agyeman et al. fuse environmental justice movements, NGO, religious and community action in this area into the notion of 'Just Sustainabilities'; 'thought of as a counterbalance, an infusion of ideas of equity and justice. ${ }^{67-69}$ Some critical work in this context also emphasizes and explores counter-cultural aspects of grassroots action. ${ }^{46,68,70,71}$ Government or sponsored accounts of community marry the relative inexpense (at least in how these things are currently measured) of community policy with neoliberal rollback. But, neither radical or neoliberal ambitions for community should be totalizing. Critical research ought to be aware of the potential for coercion through neoliberal governance, but also be alive to what community looks and feels like to those on the inside. Community activists or members can participate in these initiatives for a range of reasons, from the coopted to the progressive. Critical approaches to community and climate change aim to understand this range of actions, intertwined in more or less intimate ways with the neoliberal state. Indeed, they attempt to outline the tendencies of the neoliberal state, and what this means for community. For instance, Wright $^{72}$ found that in the UK, the pursuit of a small state in the context of austerity measures has had repercussions for community resilience, weakening communities' abilities to cope with risk, without dismissing community, or the motivations of those valuing community.

Critical approaches also acknowledge two central aspects of what community does environmentally in neoliberal contexts: first, playing on the relationship between community and individualism, and second, intervening in the relationship between community and forms of knowledge.

\section{Community versus Individualism}

Neoliberal societies seem to prize the experience of the individual above the collective. Community activism and belonging can therefore be countercultural, as are sustainable development aspirations to collective action. ${ }^{73}$ Certainly, some community groups and movements, particularly those associated with environmental issues, present themselves as attempting to create collective agency in an individualized world. The rise of neoliberal ideology is concurrent with New Social Movements: the post- '68, post-fordist, broadly liberation movements witnessed in Western societies, in which community is often either intentional, active and an agent of change, or a collective retreat from mainstream society. Under neoliberalism, individualism is not the antithesis of community; rather, the two accompany each other. The reasons for this are variously postulated: there is a perceived need to reforge social ties (Bauman highlights this need for community); identity-based social togetherness can emerge as a preferable form of community to 'community of place'; community reflects 
individualism in all but bodily scale (communities are meta-individuals $)^{74}$; in this view, individualism and community are not only concurrent, but highly connected. The carbon governmentalities literature has recently drawn attention to the ways in which the increasing use of community and the rise of individualism, harmoniously reflect one another. ${ }^{27,73,75,76}$

Despite this attempt to align the two concepts, we must not forget that neoliberalism emphasizes rational, market-mediated, individual decisions and consumer choice over traditional political mechanisms and collective action. ${ }^{77}$ Community-based initiatives are an important vehicle for understanding how these neoliberal mechanisms impact on forms of togetherness. As the tendency within neoliberal modes of governing is devolving responsibility to both the individual and market, community becomes a site, context, and scenario where atomized individuals can enact these reflexive expectations. ${ }^{30}$ Under neoliberalism 'a central part of state power is the making of environmental subjects that come to care for the environment in ways complimentary to modern government. ${ }^{78}$ Part of individualism is the production of reflexive subjects, a subjectivity concerned with constant measuring, comparison, and evaluating oneself, over and against another. ${ }^{79}$ This is a form of subjectivity that requires others to shore up ones sense of place in the world. How subjects are ordered requires a close comparison with others. This then is carried among collections of autonomous, reflexive subjects, in 'communities.' These are communities of aggregation, interest and, inevitably, competition.

The neoliberal context creates tensions then, as in an increasingly individualized society it is difficult (and surprisingly possible) to operate and organize collectively. ${ }^{80-82}$ For example Eadson and Foden find that community energy initiatives are inherently fuzzy and potentially exclusionary. ${ }^{, 83}$ The vagueness of community rhetoric can mask fundamental barriers to collective action such as social inequalities. ${ }^{84}$ As the form of community enjoined upon society is quite complimentary to processes of individualism, it becomes difficult to see the differences between this and the mainstream. Pickerill's ${ }^{85}$ work on ecohousing and ecovillages, for example, touches on many of the difficulties of carving out collective alternatives in an indifferent and foreclosed world. Meanwhile, part of community's attraction continues to be a sense that this is a space in which one can act outside of perceived norms, including individualistic ones. As critical scholars of community, we are both aware of this tension, and searching for instances of it in our empirical research. Understanding this tension is often an essential part of understanding the way(s) in which community is operationalized. Again bearing in mind Defilippis et al.'s ${ }^{2}$ twin pitfalls of community-naïvety or community-overcriticality, we suggest a productive critical balance.

Community is therefore a vehicle for 'carbon control': attempting to discipline, guide, and foster citizens to lead preferable forms of carbon lives, avoiding carbon deviance. Yet, it is also a collective form of being and becoming together. Community is an alternative to the market-mediated, calculating and comparing reflexive subjectivity increasingly enjoined on neoliberal subjects. Crucial to a critical approach is recognizing that community is regularly both/and, not either/or. Community is both a product of individual times, and a corrective and potential alternative to it.

Taking a critical perspective requires us to understand that each time community is engaged with as an arm's length agent of the state (or similar institution), it is imagined to be constituted of subjects acting in a particular way. ${ }^{86}$ Such imagined subjectivities impact in turn on how community members understand their own subjectivities as agents. This is exemplified in Hauxwell-Baldwin's analysis of the Low-Carbon Communities Challenge, which foregrounded a 'save energy, save money' message, thereby imagining a rational, self-interested subject, rather in contradiction to the fund's goal of understanding community capacity for dealing with climate change. ${ }^{28}$ Inevitably, such a framing has an impact on the day-to-day activities of the funded projects, which are trying to fulfill the requirements of funders, and which are therefore pushed into a similar conceptualization of the solution to reducing energy use.

\section{Counting Community}

Using community to govern citizens' lives in a neoliberal age is widely diagnosed. ${ }^{87-90}$ In the context of climate change, community is deployed to combat carbon deviance among populations. ${ }^{28,61,62,91,92}$ Various state schemes are putting community to use in these areas. Within the UK, England and Wales has the Low-Carbon Community Challenge and Scotland the Climate Challenge Fund. Local authorities in England now have a statutory obligation to produce a Sustainable Community Strategy. Rice ${ }^{77,78,93}$ outlines how in the absence of national legislation, US municipal, city, and community-based activity attempts to influence individuals' behavior in regards to climate change mitigation and adaptation. These processes are not confined within the English-language world and word 'community': Luxembourg's Pacte Climat 
for instance sets out a series of incremental and mandatory environmental targets for local communes to achieve.

Here, where community is used in a neoliberal manner to target carbon deviance, it often relies on fungible, perfectly substitutable indicators such as carbon footprints. The neoliberal tendency to govern through numbers-abstract, disinterested, fungible forms of knowledge par excellence-is a more global phenomenon. ${ }^{89,94}$ This form of abstract, epistemic knowledge is a particular type of 'means' in the aim of addressing certain 'ends': global environmental challenges. However, these 'means' are not necessary nor are they the only possible ways of journeying toward these 'ends.' They include what have been termed new forms of 'carbon control, ${ }^{95,96}$ involving 'calculating, measuring, and managing emissions of greenhouse gases at the level of the individual. ${ }^{75}$ This entails 'reworking state institutions around issues of carbon calculation, measurement, and monitoring., ${ }^{77}$

Research regularly indicates that funded community groups have 'a definite preference for "doing" rather than measuring the outcomes of activities, ${ }^{97}$ which can appear as 'a box-ticking exercise, or an onerous activity. ${ }^{98}$ Policy goals frequently rely on abstract indicators, using formal, explicit integers to define, know, and manage the problem. This can be summed up colloquially as: 'you can't manage what you can't measure.' A critical approach understands that these measurements and environmental knowledges are produced through certain practices, locations, and types of actor. Critical approaches do not merely substitute one indicator for another; for instance, a happiness index over GDP, or biodiversity indicator over carbon footprint. Instead we query the specific form of knowledge that has come to predominate: why numbers in the first place? We also retain an imperative to investigate what implicit assumptions and ways of thinking accompany these taken for granted forms of knowledge.

In this work, there is awareness that particular forms of knowledge have consequences. And that certain means can allow for or foreclose the opportunity for different ends. Creamer's examination of community carbon saving projects in Scotland clearly shows that the presence of government funding and associated targets for action shapes the work of these groups. ${ }^{61}$ She observes that community groups that receive funding face new challenges, in the form of competition with other groups, misaligned timeframes and demands on administration, which change the nature of their daily work. Equally Hobson et al. ${ }^{99}$ note that the presence of funding, and the technologies of evaluation that surround it, bring to light the contrasting objectives held by groups and funders, and can result in groups avoiding accessing funding in the future. Measuring and focusing on means in abstract terms, tends toward a focus on ends that are more objectively, abstractly, and distantly defined, as opposed to the often-intangible benefits of bringing people together. Objective targets in turn lead to an objective and 'aspatial' view of community, ${ }^{100}$ setting it apart from the funder and researcher, understanding community in instrumental terms rather than as a feeling of involvement. Just as Holstead et al. demonstrate how framing wind energy as instrumental and economic crowds out other rationalities and community concerns, ${ }^{101}$ when numbers predominate, the tendency is to think about instrumental rather than intrinsic goals. ${ }^{27}$ Community often produces more incidental, supplementary, qualitative, and less tangible outcomes. By definition, these can be impossible to put a number on, or to measure in the ways commonly understand by policy aims and objectives.

Hobson et al. recommend that 'funding should not be tied to overly stringent outcomes and timelines ... an argument antithetical to current modes of competitive funding' of these groups in the UK. ${ }^{97}$ Critical research drawing attention to why this is antithetical must take account of the underlying conditions and the implications of neoliberal preferences for number-based measuring.

\section{COMMUNITY AND REPRESENTATION}

The form community currently takes in response to climate change currently implies two things. First, that the community is active, and formed, founded and furthered through volunteer effort. Second, that this is claimed to be both more and less democratic, concurrently, though by different voices.

Demographic evidence in the UK suggests that community-based activism on mitigating climate change is primarily undertaken by a specific section of society. This is what Mohan calls the 'civic core'those demographically predisposed to getting involved in collective collaborations. ${ }^{102}$ Volunteers tend to be well-educated, middle-class, faith-motivated, older, and often with skills, talents, and capabilities above average. There are good reasons why this might be the case: recent parents, those living on the breadline, in fuel poverty, or in very advanced years cannot-for obvious reasons-get involved in ways others can. Often environmental movements require a certain level of education to grasp the issues and challenges of what 
can often seem quite an abstract set of issues. Note that we are clearly referencing a form of community that is active, involved and engaged here, and ignoring the communities that are unacknowledged, latent, or passively entered into (my neighborhood, my workplace, and my sports team).

Such a narrow demographic base to this form of community is not without its problems. ${ }^{103}$ Not only is the composition of these groups quite specific, the way they are organized and operated tends to be oligarchic. Creamer for instance notes how the resources and skills required in keeping successful community-based action on climate change going often can discourage people from getting involved. Specifically discussing the challenges of such groups in applying for funding, those at the forefront of this type of community tend to be 'professional, university-educated individuals with extensive project management experience and high-level accounting and budgeting skills.' As she notes: 'It is apparent that those with less training and experience would be at a disadvantage. ${ }^{, 61}$ Kenis and Mathijs perceived that those that take the lead in both problematizing and offering solutions in a community context, will dominate the ensuing action, potentially excluding those who do not share the same vision. ${ }^{104}$ Furthermore, Anantharaman's work in India documents a 'zero-waste community,' brought into being by domestic servants and waste workers, while being claimed as a success by middle-class activists. ${ }^{105}$

Appreciating that this community is active rather than latent is the key to understanding community as a form of public. Paterson outlines what we can say about 'public practices around climate change, ${ }^{106}$ starting with two arguments; first, the public is increasingly eroded by the private, and, second, governance responses to climate change require a 'reconstitution of the public sphere' (p. 149). The public we are interested in here is 'community,' and fits with Paterson's arguments-for the former that community is being eroded by the private through rollout and rollback neoliberal practices mentioned in the Critiquing Community in Western Neoliberal Contexts section. Perhaps more interestingly though, are the ways community is reconstituted as a form of public sphere. For Paterson (2014) today's publics is not to be found in (neo)classical neutral points of connection, such as an agora, but in the 'agonistic space between opposing discursive forces' (p. 169). What Paterson calls the 'public practices of climate change' requires a focus on what people do in relation to climate change. Similarly, Eden takes a broadly practice theory inspired approach to analyze Environmental Publics ${ }^{107}$ by activity focus (voting, campaigning, participating, etc.), rather than sociodemographics (age, income, residence, etc.). Community as a public form is not only willed into being by its members, or an emergent property of social identity; community can be characterized by activity as a plural, agonistic, deliberative, and intersubjectivelearning experience as Paterson suggests for publics. In critical work on community, these ideas are explored by Annaleen Kenis in thinking about the contrast between the Transition movement (which she links to a communitarian public) and Climate Justice Action (which envisages an agonistic public). ${ }^{108}$ The implications of such work for understanding representation in community are substantial: this will mean different things for these different imagined publics.

Marres and Lezaun offer an analysis of the role(s) of materiality and things in the construction of publics, ${ }^{109}$ what they call the 'physique of the public' (p. 490). The insight that matter is a tacit, constituting force in the organization of collectives is important. Primarily, because 'material perspectives on participation [like theirs] challenge a vision of public action centered on discursive or deliberative processes.' As we have said a semantic-or discursive, linguistic, even polysemic - approach to can be an important first step in analyzing community, but a critical approach will be dissatisfied with this appetizer, and need to go further in analyzing what community (or any form of public collectives) can do-or is claimed to do. ${ }^{35}$ Here, we deliberately do not specify in advance what makes up community: with or without matter as social glue. Rather, we argue that it is the attempt to conjure community into being, cajole community to pursue neoliberal agendas or conflate differences into any given community. These are precisely what we are critical of, not community itself (whatever it may or may not be).

Set against this are the ways in which evidence from those involved in community groups and movements can feel empowered, with an increased sense of agency and capacity to achieve things. $1,110-112$ These groups may be populated by a specific demographic, but they are often concerned with attempting to represent others nevertheless. Often those involved are caught in a double bind where acting individually can be insignificant, short term and require a substantial quantity of will. This form of ecovoluntarism is fraught with difficulty. But, we should not close the door to finding that a particular community may well be a good thing-only to the assumption that they all are.

This is not to fall into what North and Longhurst call the 'Goldilocks' trap: community valorized 
as a scale 'neither too top-down nor too individualistic and slow to result in change at the scale necessary. ${ }^{, 113}$ As should be clear by now, such scalar assumptions and moral qualities latent within community are precisely what this research should be critical of. Nevertheless, there remains something persistently enabling - if only at a subjective, phenomenological level-about acting as and belonging to community. Just as it would be naïve to repeat hackneyed community clichés-positive, local, harmonious, to name only a few-it would be remiss to ignore that community remains attractive, for what may be reasonable reasons.

A critical approach to community interrogates both the underlying sediment patterns of involvement in and-crucially-representation of communities. Yet it is also aware that they are very often populated and sustained by well meaning 'others.'

\section{LESSONS LEARNED AND WAYS FORWARDS}

In exploring this literature, it becomes clear that a critical approach to studying communities and climate change has some central characteristics. To start with, a critical approach typically asks questions about:

1. Meaning and function: We start with the ontological standpoint that community has multiple meanings for the different actors engaged in climate change action, meanings that perform different functions for those actors. As such communities are both politically and socially complicated, and power riven. Critical studies of community will attempt to capture both the diversity of meaning, and tensions that arise from the translation of meaning into function.

2. Neoliberal context: Armed with an insider viewpoint, and aware of the neoliberal backdrop against which community plays out, this research also starts with certain self-evident presuppositions seemingly ignored in mainstream policy and practitioner circles. Primarily, this is that governments and other powerful actors may attempt to co-opt community to their own ends. This might take the form of capture through neoliberal rollback and out, through forms of neoliberal subjectivity or capture through measurement. Part of our role as critical researchers is to be alert to these tensions and to reveal them through our work.

3. Social difference: While much of our work starts with an insider perspective, and while we recognize the work that volunteers put into community action on climate change, a critical approach requires a alertness to social difference in studying community action. This means recognizing the implications of the 'civic core' being at the helm of much of this action, as well as the potential for such action to enable democratic renewal.

As a result of both the questions asked of community and climate change, and the constructively critical approach taken to this topic, we find that this body of work tends to have a common methodological approach:

4. Ethnographic, participatory approaches: Critical community research is methodologically flexible. Yet, because they tend to begin with community, critical approaches also tend to use bespoke qualitative methods in carrying out this research. ${ }^{114}$ We find that communities are best understood from this perspective using ethnographic and/or participatory approaches. These have the benefit of emphasizing the intersection of multiple scales (local, regional, and national). Furthermore, they also enable an understanding of the lived experience of community, alongside policy understandings, in order to capture the different purposes, meanings, and uses of community at different scales.

Furthermore, the overall approach espoused by critical researchers of community and climate change, leans toward the constructively critical.

5. Constructive criticism: We attempt to take the nuanced approach required to tack between Defilippis et al. $^{2}$ celebratory or dismissive approaches to community. Rather than throwing the baby out with the bathwater, we are prepared to entertain the concepts that dismissive research sometimes reject (including 'community' itself), while retaining our critical faculties. For example, Van Veelen and Haggett, ${ }^{53}$ while critical of the often celebratory use of 'community of place,' draw attention to the crucial role place attachment plays in community-led renewable energy projects.

Given the kinds of questions being asked by this body of work, and the constructively critical approach we are attempting to embrace, there are some clear theoretical requirements to underpin our studies: 
6. Critical theory not dismissive theory: This is a body of work which must remain theoretically flexible. For our work to be critical, it is imperative that it should remain critical of itself, and the theoretical schemas it builds up. Clearly there are some theoretical outlooks that encourage critical thinking. These include (among many others) a phronetic approach, after Flyjberg ${ }^{115}$ referring to a practical wisdom. Here, critical research on community is an intellectual and practical activity. The work of Nikolas Rose and others on subjectivity ${ }^{116}$ also offers a useful set of critical tools with which to approach community and climate change. Inspiration might also be taken from critical political ecology, ${ }^{21}$ furthering the crossing of disciplinary and geopolitical knowledge boundaries. The qualities of useful theoretical approaches here are those that hold community critically but not dismissively.

\section{CONCLUSION}

We now return to Walker's call to arms. Crucially, Walker argues that a critical approach needs to be maintained. By reemphasizing his call, and documenting advances in this field in the intervening years, we seek to contribute to this sustenance. We have shown that many scholars have taken up Walker's call, critically investigating what community does in response to climate change. We have also raised the profile of this work, which can sometimes remain rather hidden from view. There are many reasons for this: many of the researchers we have pointed to here are early career researchers (inherently precarious), spread across various disciplines (less connected), without the voice or authority that comes with academic progression. Although, there are exceptions, not least the RIPPLES (Research the Interface between Policy and Practice for Local Environmental Sustainability) postgraduate and early career collective, out of which this paper partially emerges (http:// www.ripplesnetwork.org.uk). Ironically, community studies, where one might expect to find this work, can fail to satisfy: due to a focus on questions that fail to adopt the critical stance we outline here: a reification of community as an object of study, not a social condition to get involved in and for; a focus on semantic meaning, redefining what community is, not does; and either overly celebrating or dismissing both the community under investigation or those comprising such groups.

Community is a beguilingly simple word and concept, which makes such a complex social phenomenon challenging to approach, let alone claim to understand or to comprehensively evaluate. There are many significant gaps here that critical researchers need to plough ahead with investigating-not least aspects we barely touch on, gender and ethnicity to name only two. We certainly do not claim to provide the last word on this topic, but we do want to show how wrestling with how to be critical has become a central part of work in this area. It is all the more important then, that researching community in these contexts continues to journey towards Walker's guiding lodestar.

\section{REFERENCES}

1. Walker G. The role for "community" in carbon governance. WIREs Clim Change 2011, 2:777-782.

2. Defilippis J, Fisher R, Shragge E. Neither romance nor regulation: re-evaluating community. Int J Urban Reg Res 2006, 30:673-689.

3. Smith A, Hargreaves T, Hielscher S, Martiskainen M, Seyfang G. Making the most of community energies: three perspectives on grassroots innovation. Environ Plan A 2016, 48:407-432.

4. Seyfang G, Haxeltine A. Growing grassroots innovations: exploring the role of community-based initiatives in governing sustainable energy transitions. Environ Plan C Gov Policy 2012, 30:381-400.

5. McCarthy J. Devolution in the woods: community forestry as hybrid neoliberalism. Environ Plan A 2005, 37:995-1014.
6. Kumar C. Revisiting "community" in communitybased natural resource management. Community Dev J 2005, 40:275-285.

7. Holdcroft LE. The rise and fall of community development: 1950-1965 [Internet]. MSc Thesis. Department of Agricultural Economics, Michigan State University, 1976. Available at: http://ageconsearch. umn.edu/bitstream/11123/1/pb76ho01.pdf. (Accessed January 10, 2017).

8. Chambers R. Rural Development: Putting the Last First. London and New York: Longman; 1984, 10 p.

9. Roe D. The origins and evolution of the conservationpoverty debate: a review of key literature, events and policy processes. Oryx 2008, 42:491.

10. Agrawal A. Community in Conservation: Beyond Enchantment and Disenchantment Conservation \& 
Development Forum, editor. Gainesville, FL: Conservation \& Development Forum; 1997.

11. Agrawal A, Gibson CC. Enchantment and disenchantment: the role of community in natural resource conservation. World Dev 1999, 27:629-649.

12. Belsky JM. Misrepresenting communities: the politics of community-based rural ecotourism in Gales Point Manatee, Belize1. Rural Sociol 2009, 64:641-666.

13. Leach M, Mearns R, Scoones I. Environmental entitlements: dynamics and institutions in communitybased natural resource management. World Dev 1999, 27:225-247.

14. Cooke B, Kothari U, eds. Participation: The New Tyranny? London and New York: Zed Books; 2001, 207 p.

15. Mansuri G, Rao V. Community-based and -driven development: a critical review. World Bank Res Obs 2004, 19:1-39.

16. Blaikie P. Is small really beautiful? Community-based natural resource management in Malawi and Botswana. World Dev 2006, 34:1942-1957.

17. Blaikie P, Biot Y, Jackson C, Palmer-Jones R, eds. Rethinking Research on Land Degradation in Developing Countries. Washington, DC: World Bank; 1995, 139 p. (World Bank discussion papers).

18. Stott PA, Sullivan S. Political Ecology: Science, Myth and Power. London and New York: Arnold and Oxford University Press; 2000, 276 p.

19. Forsyth T. Critical Political Ecology: The Politics of Environmental Science. London and New York: Routledge; 2003, 320 p.

20. Robbins P. Political Ecology: A Critical Introduction. Malden, MA: Blackwell Pub; 2004242 p. (Critical introductions to geography).

21. Forsyth T. Community-based adaptation: a review of past and future challenges: Community-based adaptation. WIREs Clim Change 2013, 4:439-446.

22. Ford JD, Stephenson E, Cunsolo Willox A, Edge V, Farahbakhsh K, Furgal C, Harper S, Chatwood S, Mauro I, Pearce T, et al. Community-based adaptation research in the Canadian Arctic: communitybased adaptation research. WIREs Clim Change 2016, 7:175-191.

23. Dumaru P. Community-based adaptation: enhancing community adaptive capacity in Druadrua Island, Fiji. WIREs Clim Change 2010, 1:751-763.

24. Lovell H. The multiple communities of low-carbon transition: an assessment of communities involved in forest carbon measurement. Local Environ 2014, 28:1-20.

25. UK Government. The UK Government Sustainable Development Strategy. Norwich, Great Britain: Stationery Office; 2005, 186 p. (Cm).

26. Jackson R. The Silent Community? From Practicing (a)-Political Volition to Re-Politicising Difference
[Internet]. Lancaster: Lancaster University; 2015. Available at: http://eprints.lancs.ac.uk/76852/. (Accessed March 1, 2017).

27. Taylor Aiken G. Prosaic state governance of community low carbon transitions. Polit Geogr 2016, 55:20-29.

28. Hauxwell-Baldwin R. Tackling climate change through community: the politics and practice of the low carbon communities challenge. PhD Thesis, University of East Anglia, 2013.

29. Aiken G. The production, practice and potential of 'community' in Edinburgh's Transition Town Network [Internet]. PhD Thesis. Durham: Durham University, 2014. Available at: http://etheses.dur.ac.uk/ 9487/. (Accessed March 1, 2017).

30. Eadson W. State enrolment and energy-carbon transitions: syndromic experimentation and atomisation in England. Environ Plan C Gov Policy 2016, 34:1612-1631. [Internet]. Available at: http://epc. sagepub.com/lookup/doi/10.1177/ 0263774X16629445. (Accessed March 14, 2016).

31. Bell CR, Newby H. Community Studies: An Introduction to the Sociology of the Local Community. London: Allen and Unwin; 1971, 262 p. (Studies in sociology).

32. Cohen AP. The Symbolic Construction of Community. London: Routledge; 2008. Transferred to digit. pr. 128 p. (Key ideas).

33. Anderson B. Imagined Communities: Reflections on the Origin and Spread of Nationalism. London: Verso; 2003, Rev. and extended ed. 13. impression. 224 p.

34. Bauman Z. Community: Seeking Safety in an Insecure World. Cambridge: Polity Press; 2004, 159 p. (Themes for the 21st century). Reprinted.

35. Taylor Aiken G. Polysemic, polyvalent and phatic: a rough evolution of community with reference to low carbon transitions. People Place Policy 2016, 10:126-145. Online.

36. Wright K. Lived realities of local community: evidence from a qualitative case study in Leeds. Soc Policy Soc 2015, 14:555-568.

37. Taylor Aiken G. (Local-) community for global challenges: carbon conversations, Transition Towns and governmental elisions. Local Environ 2015, 20:764-781.

38. Horkheimer M. Nachgelassene Schriften 1914-1931. In: Schmidt A, ed. Teil 1. Vorlesung über die Geschichte der neueren Philosophie. Frankfurt am Main: Fischer-Taschenbuch-Verl; 1987, 493 p. (Gesammelte Schriften).

39. Warren CR, Birnie RV. Re-powering Scotland: wind farms and the "energy or environment?" debate. Scott Geogr J 2009, 125:97-126. 
40. Bomberg E, McEwen N. Mobilizing community energy. Energy Policy 2012, 51:435-444.

41. Feola G, Him MR. The diffusion of the Transition Network in four European countries. Environ Plan A 2016, 48:2112-2115. [Internet]. Available at: http:// epn.sagepub.com/lookup/doi/10.1177/

0308518X16630989. (Accessed May 16, 2016).

42. Feola G, Nunes R. Success and failure of grassroots innovations for addressing climate change: the case of the Transition Movement. Glob Environ Change 2014, 24:232-250.

43. Bulkeley H, Fuller S. Low carbon communities and social justice. JRF viewpoints Ref. 2741, 2012.

44. Burchell K, Rettie R, Roberts T. Community, the very idea! Perspectives of participants in a demand-side community energy project. People Place Policy 2014, 8:168-179. Online.

45. Fuller S, Bulkeley H. Energy justice and the low carbon transition: assessing low carbon community programmes in the UK. In: Energy Justice in a Changing Climate. London: Zed Books; 2013, 61-78.

46. Kent J. Community Action and Climate Change. London and New York: Routledge/Earthscan; 2016174 p.

47. North P. The politics of climate activism in the UK: a social movement analysis. Environ Plan A 2011, 43:1581-1598.

48. Gilbert J. Common Ground: Democracy and Collectivity in an Age of Individualism. London: Pluto Press; 2014, 258 p.

49. de Wilde M. Brave New Neighbourhood: Affective citizenship in Dutch territorial governance [Internet]. PhD Thesis. Amsterdam: Universiteit van Amsterdam, 2015. Available at: http://dare.uva.nl/search?metis. record.id=476731. (Accessed March 1, 2017).

50. de Wilde M, Hurenkamp M, Tonkens E. Flexible relations, frail contacts and failing demands: how community groups and local institutions interact in local governance in the Netherlands. Urban Stud 2014, 51:3365-3382.

51. Russi L. Everything Gardens and Other Stories: Growing Transition Culture. Plymouth: University of Plymouth Press; 2015.

52. Phillips M, Dickie J. Climate change, carbon dependency and narratives of transition and stasis in four English rural communities. Geoforum 2015, 67:93-109.

53. van Veelen B, Haggett C. Uncommon ground: the role of different place attachments in explaining community renewable energy projects. Sociol Rural 2016 [Internet]. Available at: http://doi.wiley.com/10.1111/ soru.12128. (Accessed March 1, 2017).

54. Braunholtz-Speight T. Scottish community land initiatives: going beyond the locality to enable local empowerment. People Place Policy 2015, 9:123-138. Online.

55. Braunholtz-Speight T. Power and community in Scottish community land initiatives. Unpublished $\mathrm{PhD}$ Thesis. Aberdeen: University of the Highlands and Islands, and University of Aberdeen, 2015.

56. Markantoni M, Woolvin M. The role of rural communities in the transition to a low-carbon Scotland: a review. Local Environ 2015, 20:202-219.

57. Büchs M, Saunders C, Wallbridge R, Smith G, Bardsley N. Identifying and explaining framing strategies of low carbon lifestyle movement organisations. Glob Environ Change 2015, 35:307-315.

58. Smith N. Uneven Development: Nature, Capital, and the Production of Space. Oxford and Cambridge, MA: B. Blackwell; 1991, 219 p.

59. Williams R. Keywords: A Vocabulary of Culture and Society. Rev. ed. New York: Oxford University Press; 1985, 349 p.

60. Markantoni M. Low carbon governance: mobilizing community energy through top-down support? Low carbon governance. Environ Policy Gov 2016, 26:155-169.

61. Creamer E. The double-edged sword of grant funding: a study of community-led climate change initiatives in remote rural Scotland. Local Environ 2015, 20:981-999.

62. Creamer E. "Community": the means and ends of sustainability? Exploring the position and influence of community-led initiatives in encouraging more sustainable lifestyles in remote rural Scotland. PhD Thesis. Edinburgh: University of Edinburgh, 2015.

63. Rosol M. Community Volunteering as Neoliberal Strategy? Green space production in Berlin. Antipode 2012, 44:239-257.

64. Jones R, Pykett J, Whitehead M. Psychological governance and behaviour change. Policy Polit 2013, 41:159-182.

65. Jones R, Pykett J, Whitehead M. The geographies of soft paternalism in the UK: The rise of the Avuncular State and changing behaviour after neoliberalism: geographies of soft paternalism in the UK. Geogr Compass 2011, 5:50-62.

66. Pykett J, Jones R, Whitehead M, Huxley M, Strauss K, Gill N, McGeevor K, Thompson L, Newman J. Interventions in the political geography of "libertarian paternalism." Polit Geogr 2011, 30:301-310.

67. Agyeman J. Introducing Just Sustainabilities: Policy, Planning, and Practice. London: Zed Books; 2013, $205 \mathrm{p}$.

68. Agyeman J. Sustainable Communities and the Challenge of Environmental Justice. New York: New York University Press; 2005, 245 p. 
69. Agyeman J, Schlosberg D, Craven L, Matthews C. Trends and directions in environmental justice: from inequity to everyday life, community, and just sustainabilities. Annu Rev Environ Resour 2016, 41:321-340.

70. Chatterton P. The Rocky road of post-capitalist grassroots experimentation. In: Dastbaz M, Gorse C, eds. Sustainable Ecological Engineering Design [Internet]. Cham: Springer International Publishing; 2016, 31-44. Available at: http://link.springer.com/10.1007/ 978-3-319-32646-7_4. (Accessed June 22, 2016).

71. Longhurst $\mathrm{N}$. The emergence of an alternative milieu: conceptualising the nature of alternative places. Environ Plan A 2013, 45:2100-2119.

72. Wright K. Resilient communities? Experiences of risk and resilience in a time of austerity. Int $J$ Disaster Risk Reduct 2016, 18:154-161. [Internet]. Available at: http://linkinghub.elsevier.com/retrieve/ pii/S2212420916301169. (Accessed June 22, 2016).

73. Middlemiss L. Individualised or participatory? Exploring late-modern identity and sustainable development. Environ Polit 2014, 23:929-946.

74. Aiken G. Community transitions to low carbon futures in the Transition Towns Network (TTN): community as seen by Transition Towns. Geogr Compass 2012, 6:89-99.

75. Paterson M, Stripple J. My Space: governing individuals' carbon emissions. Environ Plan Soc Space 2010, 28:341-362.

76. Rutland T, Aylett A. The work of policy: actor networks, governmentality, and local action on climate change in Portland, Oregon. Environ Plan Soc Space 2008, 26:627-646.

77. Rice JL. Public targets, private choices: urban climate governance in the Pacific Northwest. Prof Geogr 2014, 66:333-344.

78. Rice JL. Climate, carbon, and territory: greenhouse gas mitigation in Seattle, Washington. Ann Assoc Am Geogr 2010, 100:929-937.

79. Verhaeghe P. What about Me? the Struggle for Identity in a Market-Based Society. Melbourne and London: Scribe; 2014, 265 p.

80. Gibson-Graham JK. Take Back the Economy: An Ethical Guide for Transforming Our Communities. Minneapolis: University of Minnesota Press; 2013.

81. Gibson-Graham JK. A Postcapitalist Politics. Minneapolis: University of Minnesota Press; 2006, 276 p.

82. Gibson-Graham JK. The End of Capitalism (As We Knew It): A Feminist Critique of Political Economy. 1st University of Minnesota Press ed. Minneapolis: University of Minnesota Press; 2006, 299 p.

83. Eadson W, Foden M. Editorial: critical perspectives on community energy. People Place Policy 2014, 8:145-148, Online.
84. Catney P, MacGregor S, Dobson A, Hall SM, Royston S, Robinson Z, Ormerod M, Ross S. Big society, little justice? Community renewable energy and the politics of localism. Local Environ 2014, 19:715-730.

85. Pickerill J. Eco-Homes: People, Place and Politics. London: Zed Books; 2016, 360 p.

86. Franklin A, Marsden T. (Dis)connected communities and sustainable place-making. Local Environ 2015, 20:940-956.

87. Dean M. Governmentality: Power and Rule in Modern Society. 2nd ed. London and Thousand Oaks, CA: SAGE; 2010, 294 p.

88. Rose N. Community, Citizenship, and the third Way. Am Behav Sci 2000, 43:1395-1411.

89. Rose NS. Powers of Freedom Reframing Political Thought [Internet]. Cambridge and New York: Cambridge University Press; 1999. Available at: http://site. ebrary.com/id/2000829. (Accessed August 5, 2013).

90. Wallace A. Remaking Community? New Labour and the Governance of Poor Neighbourhoods. London: Routledge; 2016.

91. Bulkeley H. Accomplishing Climate Governance [Internet]. Cambridge: Cambridge University Press; 2015. Available at: 10.1017/CBO9781139839204. (Accessed May 13, 2016).

92. Taylor Aiken G. Common sense community? The climate challenge fund's official and tacit community construction. Scott Geogr J 2014, 130:207-221.

93. Rice JL. An urban political ecology of climate change governance: an urban political ecology of climate change governance. Geogr Compass 2014, 8:381-394.

94. Badiou A. Number and Numbers. Cambridge: Polity; 2008, 240 p, Reprinted.

95. Jonas AEG, Gibbs D, While A. The new urban politics as a politics of carbon control. Urban Stud 2011, 48:2537-2554.

96. While A, Jonas AEG, Gibbs D. From sustainable development to carbon control: eco-state restructuring and the politics of urban and regional development: from sustainable development to carbon control. Trans Inst Br Geogr 2010, 35:76-93.

97. Hobson K, Mayne R, Hamilton J. Monitoring and evaluating eco-localisation: lessons from UK low carbon community groups. Environ Plan A 2016, 48:1393-1410. [Internet]. Available at: http://epn. sagepub.com/lookup/doi/10.1177/ 0308518X16640531. (Accessed May 13, 2016).

98. Merritt A, Stubbs T. Incentives to promote green citizenship in UK Transition Towns. Development 2012, 55:96-103.

99. Hobson K, Hamilton J, Mayne R. Monitoring and evaluation in UK low-carbon community groups: 
benefits, barriers and the politics of the local. Local Environ 2016, 21:124-136.

100. Franklin A, Newton J, Middleton J, Marsden T. Reconnecting skills for sustainable communities with everyday life. Environ Plan A 2011, 43:347-362.

101. Holstead KL, Galán-Díaz C, Sutherland L-A. Discourses of on-farm wind energy generation in the UK farming press. J Environ Policy Plan 2016, 29:1-17.

102. Mohan J. Geographical Foundations of the Big Society. Environ Plan A 2012, 44:1121-1129.

103. Grossmann M, Creamer E. Assessing diversity and inclusivity within the Transition movement: an urban case study. Environ Polit 2016, 20:1-22.

104. Kenis A, Mathijs E. De)politicising the local: the case of the Transition Towns movement in Flanders (Belgium. J Rural Stud 2014, 34:172-183.

105. Anantharaman M. Networked ecological citizenship, the new middle classes and the provisioning of sustainable waste management in Bangalore, India. J Clean Prod 2014, 63:173-183.

106. Paterson M. Climate re-public: practicing public space in conditions of extreme complexity. In: Best J, Gheciu A, eds. The Return of the Public in Global Governance [Internet]. Cambridge: Cambridge University Press; 2014, 149-172. Available at: http://ebooks. cambridge.org/ref/id/CBO9781107281837A018. (Accessed January 13, 2017).

107. Eden S. Environmental Publics [Internet]. London: Routledge; 2017Available at: http://search.ebscohost. com/login.aspx?direct=true \&scope $=$ site $\& \mathrm{db}=$ nlebk $\&$ $\mathrm{db}=$ nlabk\&AN=1435609. (Accessed January 13, 2017).
108. Kenis A. Ecological citizenship and democracy: communitarian versus agonistic perspectives. Environ Polit 2016, 25:949-970.

109. Marres N, Lezaun J. Materials and devices of the public: an introduction. Econ Soc 2011, 40:489-509.

110. Mulugetta Y, Jackson T, van der Horst D. Carbon reduction at community scale. Energy Policy 2010, 38:7541-7545.

111. Middlemiss L. The power of community: how community-based organizations stimulate sustainable lifestyles among participants. Soc Nat Resour 2011, 24:1157-1173.

112. Middlemiss L. The effects of community-based action for sustainability on participants' lifestyles. Local Environ 2011, 16:265-280.

113. North P, Longhurst N. Grassroots localisation? The scalar potential of and limits of the "Transition" approach to climate change and resource constraint. Urban Stud 2013, 50:1423-1438.

114. Dunkley RA, Franklin A. Failing better: the stochastic art of evaluating community-led environmental action programs. Eval Program Plann 2017, 60:112-122.

115. Flyvbjerg B. Making Social Science Matter: Why Social Inquiry Fails and How It Can Succeed Again. Oxford and New York: Cambridge University Press; 2001, 204 p.

116. Rose N. Identity, Genealogy, History. In: Questions of Cultural Identity [Internet]. London: SAGE Publications Ltd; 2011, 128-150. Available at: http://sk. sagepub.com/books/questions-of-cultural-identity/n8. xml. (Accessed June 22, 2016). 